то минимум потерь при $H_{\text {загр }} / H_{\text {инд. }}=0,875 ; 0,5$ и 0,0625 снизился еще на $11 \%, 6 \%$ и $2 \%$ соответственно. Сумма перечисленных факторов определяет ход зависимостей и ту величину, на которую могут снижаться электрические потери в секциях тигля. Часто соотношение мощности в загрузке и мощности потерь в тигле не позволяет пренебречь последними. В этом случае учет результатов исследования поможет при проектировании индукционных установок и систем управления ими.

$$
* * *
$$

1. Программа расчёта электромагнитных параметров индукционной системы с разрезным проводящим тиглем / Свид. №2007614478 (рег. 24.10.2007). Правообладатели: Позняк И.В. Авторы: Позняк И.В., Шатунов А.Н., Печенков А.Ю. // Программы для ЭВМ. Базы данных. Топологии интегральных микросхем. - М.: ФГУ ФИПС, 2008.- №1.- С. 74.

2. Исследование энергетических характеристик индукционной системы с холодным тиглем / Шатунов А.Н., Позняк И.В., Печенков А.Ю. и др. // Проблемы управления и моделирования в сложных системах: Труды XII Международной конференции (21-23 июня 2010 г. Самара, Россия). - Самара: Самарский научный центр РАН, 2010.- С. 100-104.

\title{
Швецова В.В. ${ }^{1}$, Вернер Н.Н. ${ }^{2}$ \\ Современные тенденции технического развития лесозаготовительного производства в России \\ ${ }^{1}$ Военная академия связи имени Маршала Советского Союза С.М. Буденного \\ ${ }^{2}$ Санкт-Петербургский государственный лесотехнический университет имени С.М. Кирова» \\ (Россия, Санкт-Петербург)
}

doi:10.18411/lj-07-2018-35

idsp: 000001:lj-07-2018-35

\section{Аннотация}

На основании обзора современных литературных источников, а также личного опыта, в статье рассмотрены современные тенденции технического развития лесозаготовительного производства в России, включая машины и оборудование для заготовки древесины и лесовосстановления.

Ключевые слова:Лесозаготовительное производство, системы машин, лесосечные работы, лесовосстановительные работы.

\section{Abstract}

On the basis of the review of modern literary sources, as well as personal experience, the article considers modern trends in the technical development of logging production in Russia, including machines and equipment for wood harvesting and reforestation.

Keywords: Logging production, machinery systems, logging, reforestation.

В настоящее время, в России, лесное машиностроение находится в глубоком упадке [1]. Во всех областях лесозаготовительного производства, к которым относятся лесосечные работы, транспорт леса, лесоскладские работы, и лесовосстановительные работы, преобладает техника иностранного производства [2].

Из-за засилья импортной техники, при росте курсов основных иностранных валют резко повышается себестоимость заготавливаемой древесины, что связано с повышающимися расходами на расходные материалы и запасные части, а также приобретение новой техники, взамен выбывающей [3]. Ранее мелкие и средние лесозаготовительные предприятия России предпочитали приобретать импортные машины и оборудование бывшие в употреблении у иностранных коллег. Но фактически заградительные пошлины, введенные в России на ввоз бывшей в употреблении техники 
практически закрыли эту нишу рынка и возможность относительного недорого пополнения парка техники для отечественных лесозаготовительных предприятий [4].

С другой стороны, введенные против России торговые санкции, и ответные антисанкции, дают экономический шанс на восстановление практически прекратившего свое существование лесного машиностроения в России [5].

Но сейчас необходимо определить наиболее перспективные ниши рынка машин и оборудования лесозаготовительного производства, которые могли бы быть эффективно освоены отечественными машиностроительными предприятиям. Технологический процесс заготовки древесины начинается с валки деревьев, которая может выполняться при помощи бензиномоторных пил или лесозаготовительных машин. Бензиномоторные пилы в России не выпускаются с декабря 2009 г. [6], а выпуск лесозаготовительных машин, в лучшем случае, представляет единичные экземпляры, да и то, основанные на импортных комплектующих [7]. В этой связи можно сделать вывод, что быстро нагнать катастрофическое техническое отставание разработок в машинах и оборудовании для валки деревьев не представляется возможным.

Следующей технологической операцией лесосечных работ является трелевка лесоматериалов, которые могут представлять собой деревья с кроной, хлысты, или сортименты. Для трелевки, в большей части случаев, используются колесные или гусеничные тракторы с различным технологическим оборудованием: чокерные, бесчокерные, скиддеры, и форвардеры [8]. В этой нише рынка российские производители, в принципе, могут составить конкуренцию иностранным производителям, особенно для мелких лесозаготовительных предприятий, которые не обладают финансовыми возможностями покупать и обслуживать дорогостоящую импортную технику. Например, для наиболее распространенной в настоящее время в Европейской части России скандинавской технологии заготовки древесины, предусматривающей трелевку сортиментов, получаемых у пня, при помощи форвардеров, участниками научной школы «Инновационные разработки в области лесозаготовительной промышленности и лесного хозяйства» разработан целый ряд концептов $[9,10,11]$, которые вполне могут быть, с небольшими финансовыми и временными затратами, внедрены в производство даже небольших машиностроительных заводов.

Отдельным блоком перспективных отечественных разработок являются технические разработки в области освоения переувлаженных и заболоченных лесосек, которые становятся все большей проблемой для отечественных лесозаготовителей, в связи с уменьшением запасов спелых и перестойных насаждений в доступных эксплуатационных лесах, расположенных на почвогрунтах I и II категории, а также в связи со все более заметным потеплением климата, приводящем к существенному сокращению периода устойчивой зимней заготовки древесины $[12,13]$.

Для выполнения работ по очистке лесосек и лесовосстановлению также разработано технологическое оборудование, которым можно по модульному принципу оснащать базовые тракторы [14].

Можно утверждать, что внедрение в производство таких, относительно дешевых и не требующих значительной переналадки производства, разработок является наиболее перспективным направлением технического развития лесозаготовительного производства в России.

$$
* * *
$$

1. Григорьев И.В., Куницкая О.А. Перспективные направления опытно-конструкторских работ в лесном машиностроении // Повышение эффективности лесного комплекса: материалы третьей Всероссийской научно-практической конференции с международным участием. 2017. С. 53-56.

2. Григорьев И.В., Григорьева О.И., Нгуен Ф.З. Система машин и технология работ для малообъемных лесозаготовок // Повышение эффективности лесного комплекса: материалы третьей Всероссийской научно-практической конференции с международным участием. 2017. С. 51-53. 
3. Григорьев И.В., Чураков А.А. Перспективный машинный комплекс для заготовки древесины // Природные ресурсы и экология дальневосточного региона: материалы II международного научнопрактического форума. 2017. С. 170-175.

4. Григорьев И.В., Григорьева О.И., Куницкая О.А. Переработка древесины на лесосеке: перспективы развития // Энергия: экономика, техника, экология. 2017. № 2. С. 27-33

5. Григорьев И.В., Григорьева О.И., Вернер Н.Н. Системы машин для создания и эксплуатации лесных плантаций // Актуальные направления научных исследований XXI века: теория и практика. 2017. Т. 5. № 5 (31). С. 438-443

6. Галактионов О.Н., Гаспарян Г.Д., Григорьев И.В., Григорьева О.И., Куницкая О.А., Лапшин С.О., Перский С.Н., Суханов Ю.В., Сыромаха С.М., Шегельман И.Р. Бензиномоторные пилы. Устройство и эксплуатация. Учебник. СПб.: Издательско-полиграфическая ассоциация высших учебных заведений, 2017. $-206 \mathrm{c}$.

7. Григорьев И.В., Григорьев М.Ф., Степанова Д.И. Перспективы модульных систем машин для лесозаготовительного производства в Якутии // Актуальные направления научных исследований XXI века: теория и практика. 2017. Т. 5. № 9 (35). С. 74-77

8. Григорьев И.В., Куницкая О.А., Тамби А.А. Повышение эффективности проведения малообъемных лесозаготовок // Устойчивое развитие науки и образования. 2017. № 2. С. 159-167.

9. Григорьев И.В., Чураков А.А. Совершенствование конструкции активного полуприцепа форвардера на базе сельскохозяйственного колесного трактора // Транспортные и транспортно-технологические системы: материалы Международной научно-технической конференции. 2018. С. 84-88.

10. Григорьев И.В., Чураков А.А., Григорьева О.И. Перспективная конструкция гусеничного форвардера // Транспортные и транспортно-технологические системы материалы международной научнотехнической конференции. 2017. С. 140-144.

11. Григорьева О.И. Эффективность транспортно-технологических систем для лесного хозяйства // Транспортные и транспортно-технологические системы Материалы Международной научнотехнической конференции. 2018. С. 79-83.

12. Григорьев И.В., Свойкин Ф.В., Григорьева О.И., Никифорова А.И. Повышение эффективности освоения заболоченных лесосек в теплый период года // Повышение эффективности лесного комплекса: материалы Второй Всероссийской научно-практической конференции с международным участием, посвященной 65-летию высшего лесного образования в Республике Карелия. 2016. С. 68-70.

13. Григорьев И.В., Свойкин Ф.В., Григорьева О.И. Транспортная система для сбора и трелевки древесины в условиях заболоченных лесосек // Транспортные и транспортно-технологические системы Материалы Международной научно-технической конференции. 2016. С. 93-97

14. Григорьева О.И. Новая машина для очистки лесосек // Актуальные направления научных исследований XXI века: теория и практика. 2014. Т. 2. № 5-3 (10-3). С. 96-99.

\section{РАЗДЕЛ VIII. МЕДИЦИНА}

\section{Ерина И.А. \\ Жизнь замечательного врача Александра Дмитриевича Меньшова}

Астраханский государственный медицинский университет (Россия, Астрахань)

doi:10.18411/lj-07-2018-36

idsp: 000001:lj-07-2018-36

\section{Аннотация}

В статье представлена информация о выдающемся деятеле здравоохранения Астраханской области Александре Дмитриевиче Меньшове, повествуется о его нелегком пути в медицину. Наряду с высоким профессионализмом и талантом, Александра Дмитриевича отличала четкая гражданская позиция и активная общественная деятельность.

Ключевые слова: медицина, Астрахань, врач, клиника кожных и венерических болезней. 